\title{
Implementation of Blended Learning Innovation in Graph Theory Application Course to Face the Education Challenge in the $21^{\text {st }}$ Century
}

\author{
Sapti Wahyuningsih, Darmawan Satyananda \\ Mathematics Department \\ Universitas Negeri Malang \\ Malang, Indonesia \\ sapti.wahyuningsih.fmipa@um.ac.id
}

\author{
Anusua Ghosh \\ University of South Australia \\ Adelaide, Australia \\ anusua.ghosh@mymail.unisa.edu.au
}

\begin{abstract}
Facing the education challenges in the 21st century, Indonesia needs resources that have systematic, logical, creative and cooperative problem-solving skills. A learning alternative in constructivist view that can be applied to improve students' activity and creativity is to apply blended learning innovation in the Graph Theory Application course that combines some types of learning: face-to-face, offline, on line and direct experience in the field. Online learning is done by using ICT module that utilizes Google map. Indirect experience learning in the field, students work together in a group to gain problem-solving experience in the industry.
\end{abstract}

To know the creative thinking process of students in identifying and solving the problems, the researchers used Creative Problem Solving (CPS) model. The searching of the thinking process employing CPS model showed that in step of (1) objective finding, the students were creative in identifying and finding objectives. In stage of (2) fact-finding, the groups of students were creative in collecting data obtained from field surveys, meanwhile in next stage of (3) problem-finding, the students were less creative in finding problems. At this stage, the students were difficult in modeling problems so a guidance was provided to them. In stage of (4) idea-finding, the students were creative in finding ideas to choose the algorithms used. In last two steps of (5) idea evaluation and (6) idea- implementation, the students were creative in implementing the problems into the program and analyzing the process.

From the identification of the thinking process using CPS model, the students were creative in the steps of objectivefinding, fact-finding, idea-finding, idea evaluation, and idea implementation. However, in problem-finding step, they were less creative in modeling real problem into graph application problem.

Keywords - graph theory application, blended learning, problem-solving, CPS model

\section{INTRODUCTION}

Science and technology are evolving so fast that education is required to respond to these developments. Various efforts have been made to improve the quality of education, in the form of improvements and procurement of learning resources, improvement of educational facilities and infrastructure, and improvement of learning innovation. Referring to the development of the State University of Malang/Universitas Negeri Malang (UM) focusing on a center of excellence in Learning Innovation field, all UM academic communities should be ready to welcome this demand.

The education transformation in the 21 st century requires that learning patterns must change so that the world of education becomes relevant to the challenges and opportunities in real life. Facing the challenges of scientific and technological development as well as information requires high skilled resources which involve critical thinking, systematic, logical, creative and effective collaborative skills. The world of work today also demands the ability to work together in teams, problem-solving skills, self-directed skills, critical thinking skills, technological skills and effective communication skills. The abilities mentioned above are in line with the demands of 21 st century-skills and must be developed systematically in the world of education so that the learning process should be able to encourage the creation of these capabilities. In addition to academic ability, the world of education should be able to create human beings who have the ability to learn, adapt and innovate [1].

In facing challenges in the 21st century, students are required to have academic skills (hard skills), and also improve their personal skills (soft skills). The way of thinking according to the challenges in the 21 st century needs to be developed in the learning of mathematics. Mathematics can develop creative activities that involve imagination, intuition, and discovery by developing thoughts that are divergent, original, curious, predicting and guessing, and experimenting. 
One of the alternative learning in constructivism view that can be applied to improve student's activity and creativity is by applying Blended Learning. Blended Learning is a learning innovation that combines face-to-face, independent learning (learning with the various modules that have been provided) as well as online independent learning [2]. Research on the successful application of blended learning in higher education can be seen in [2]-[6].

This article discussed blended learning innovation implemented to the Graph Theory Application course. This application combines the blended learning elements mentioned above, as well as direct experience of students in the real field (industry) in the form of field surveys. The later activities have not been done according to the above reference.

The characteristics of this course are applied materials that can be used to solve some problems in daily life. The learning outcomes of this material are, among others, able to understand problems and develop problem-solving algorithms, think critically to understand problems, design mathematical models, complete models, interpret the solutions obtained, and plan as well as control the optimization process in industry, decision making, and business (catalogue of FMIPA, 2016).

Some researchers related to graph theory and its application have been performed, such as TSP [7], the characteristics of MTVRP solution [8], development of ICT-based application module [9], the characteristics of VRP variant solution [10], implementation of local search in VRP variants [11]. As a result of the researchers, some computer applications related to VRP case problem-solving have been made, as in [12], and [13].

Considering the characteristics of the Graph Theory Application course, blended learning innovation in universities can be developed from Geraldine [14] to (1) face-to-face learning in the form of discussion of portfolio problems made by students, (2) offline learning independently through various modules provided, (3) online learning with ICT-based modules, (4) direct experience learning in the field by conducting a survey of problems in industry/related agencies. In this direct learning, students in the group propose issues to be solved. Compilation of a real-time problem is what will be solved with the appropriate algorithm.

Aside from being a product of creative thinking, problemsolving is also seen as cognitive activity [15]. Learning is the process of how to obtain or process information, hence it takes a cognitive approach to know how the process of creative thinking when students ask the problem. Alex Osborn developed a creative process model called Creative Problem Solving (CPS) model [16]. The CPS model consists of six steps: objective-finding, fact-finding, problem finding, ideafinding, Solutions-finding (ideas evaluation), and acceptancefinding/idea- implementation. Those steps drive to a creative process to know the students' creative thinking process. This article describes the results of the search process of the students' creative thinking in problem-solving of field survey results in Graph Theory Application course by using CPS model.

\section{LITERATURE REVIEW}

\section{A. Blended Learning}

Another term of blended learning often used is a hybrid course. The original meaning, as well as the most common term of blended learning,, refer to learning that combines or mixes face-to-face learning and computer-based learning (online and offline).

Blended Learning combines face-to-face learning with computer-based learning. That is, learning with a learning technology approach that combines learning resources in the form of face-to-face with the teacher as well as those things contained in computer media, cell phones or smartphones, satellite television channels, video conferencing and the other electronic media. Learner and teacher/facilitator work together to improve the quality of learning. The main purpose of blended learning is to provide opportunities for learners with various characteristics to become self-sustaining, sustainable, and developing throughout life so that the learning will be more effective, more efficient, and more interesting.

\section{B. Creative and Creativity}

Creative contains the sense of having creativity, being able to realize the ideas and feelings to create a composition with new colors and nuances. The efforts to be creative are related to the enthusiasm and passion known as the substantial factor at the peak level of work. However, many people ignore creativity because they do not realize the benefits of creativity. The term of creativity is often used in school, corporation or environmental environments. The development of this creativity is necessary to face the challenges in the $21 \mathrm{st}$ century.

In the educational situation, the teaching and learning process is one of the forms of creative activities. Through the learning process, student creativity can be nurtured and developed. Student creativity needs to be trained so that its appearance arises when facing a problem-solving. Creative thinking according to Krulik \& Rudnick [17], is in the highest level of reasoning thinking above recall level. In reasoning, there are basic thinking, critical thinking, and creative thinking.

Some researchers of tracing thinking process in mathematics (including problem-solving process and the strategies) have been performed by [18]-[23].

\section{Problem-Solving}

Problem Solving is a major thinking skill because it involves the other ways of thinking: creative and analytical thinking for decision making.

- Creative Thinking is thinking that provides a new perspective or captures new opportunities that bring new ideas that have never existed. Creative is also a new combination of old ideas into a new, better idea.

- Analytical Thinking is thinking that uses a step or logical steps. The analytical thinking step is to test a statement or proof with objective standards, by looking 
under the surface to the root of the problem, weighing or deciding on the basis of logic.

There are two activities in problem-solving:

- Problem Interpretation, also known as defining problems with creative thinking

- Problem-Solving Strategy; making a selection of the best problem-solving strategies.

The six steps of Creative Problem Solving (CPS) model from Alex Osborn lead a creative process to know the creative thinking process of students. Another researcher, Silver [24], identified creativity through the problem-solving. Leung [25], argued that filing a problem can be used to understand the process of creative thinking.

\section{Google Map service}

A wide range of computer technologies that refer to geographic data is called Geographic Information Systems (GIS). It includes databases, application programs, and the other hardware's such as GPS (Global Positioning System) for accurate geographical positioning of an object with the help of satellites [26]. The contents of the database may include geographic coordinates, roads connecting one place to another (including its length, type: toll or not, its direction: one way or two way, or type of vehicle that can pass the road), any objects in the area, images or videos relevant to the road, the level of road density, the speed of the moving vehicle, the events occurring in the street, as well as many more data.

Google Map is one of the API services provided by Google, for the purposes of accessing geographic data owned by Google. This service can be used by various parties to create applications that provide mapping solutions in the application. Providing this solution can be used to view a particular location, find the position of an address, find the distance from one position to another, look for direction from one position to another, and the other matters related to the mapping aspect [27].

For the purposes of creating web-based applications with Google Map, there are two versions of the service that can be used: Google Web API (utilizing Javascript) and Google Web Service API. Basically, all services in the Web Service API are available in the Web API, but not vice versa. Services in the form of Web APIs are devoted to interactivity and access in real time, such as displaying maps, creating markers, displaying routes and directions within folders. The disadvantage is that the script is located in the client and it can be seen by the others including the API key used (the key to access Google services) so that it is vulnerable to be misused. The Web service API is located on the server and what appears is only the result of the script execution. The combination of API in the form of Javascript and web service, as well as the setting of project configuration, are required so that the codes are not misused.

\section{RESEARCH METHOD}

Insert the contents in the on-line platform

Insert the contents in the free-text scoring tool

Students attend to lessons and use the computer tools

The computer tools keep track of the students' progress

Lecturers keep track of the students' progress

Fig. 1. Scheme of blended learning methodology according to Martin (2012)

Fig. 1 depicts the scheme of blended learning methodology. The following section describes the implementation of blended learning in Graph Theory Application lectures, adapted from Perez-Martin et al. [28]. The methodology used in this research:

- First step: Introducing the content. This step was discussed in the lecture plan (RPS) which contained the design of materials in Graph Theory Application that would be discussed, the off-line learning plan, the field survey in the industry by proposing problems to be solved, and online learning.

- Second step: introducing the contents of the free-text scoring system. In this step, an evaluation was performed for the feedback.

- Third step: the students start using the computer tools. Students started to do online learning.

- Fourth step: the tracking. In this step, students' ability in using online learning was evaluated

\section{RESULTS AND DISCUSSION}

The steps of implementation of blended learning in Graph Theory Application lectures are:

\section{A. First step:}

Introducing the content. In the first round of lectures, the lecturers discussed the lecture plan (RPS) which contained the material design of the Graph Theory Application course that would be discussed. They were algorithms in Traveling Salesman Problem (TSP) variants and its application, matching in bipartition network, matching in non-bipartition network and its application, algorithms for maximum flow and their application, algorithms for minimum cost flow and their application, Vehicle Routing Problem (VRP) modeling and implementation, and network implementation for project scheduling. Offline learning used module materials, textbooks, and presentation materials. In this learning, students conducted group discussions, presented discussion results and delivered questions and answers. 


\section{B. Second step}

Introducing the contents of the free-text scoring system. In this step, an evaluation was performed for the feedback. To know the understanding, students needed to be evaluated in process of group discussion, the understanding of the material at the time of the presentation and the final evaluation were carried out by doing the written test. After a review of materials and students' understanding of graph theory was stated well, a group of students conducted field surveys to industry/related agencies.

\section{Third step}

The students started using the computer tools. Students had started doing web-based learning in the form of operating a web-based CVRP application utilizing Google Map. This application can be used to determine customer location, find the distance between customer and depot, determine the demand and capacity of the vehicle, and find the shortest route using Sequential Insertion algorithm [13].

\section{Fourth step}

The tracking. In this step, the evaluation of students' ability in using online learning was conducted. In addition, the ability of students in solving the problem of survey results was described to trace students' creative thinking process in solving the problem of field survey results. The trace for students' creative thinking process used the CPS model.

Before students took the third step, they had a field survey. They brought a proposal to an industry that runs a distribution business. The type of industry was chosen based on their research of a problem in graph theory. In there, they took the data the distribution type, the volume of distributed goods, and route of distribution. The students needed to be creative in formulating the problem and its solution.

The results of field survey data were then presented in the form of graph model, interpretation of graph vertices, graph edge, edge weight or weight of graph vertices. Narrative problems and problem-solving were made then as well.

Online learning activities that were the part of Graph Theory Application lectures utilized web-based applications to solve CVRP problems. The application was web-based because it required access to the Google Map service. Access to the Google Map API was employed to gain the distance between customers, as the weight of the graph edges.

The trace of thinking process using CPS model on the problem-solving survey results showed that:

- At stage (1) of objective-finding, the students were creative in identifying and finding objectives; in this case, determining the purpose of the survey in accordance with the group topic. The way to do it was by identifying theories, identifying industry/agencies, and browsing the website to find out the industry agency profile to be addressed. More than $85 \%$ of students could do the finding.

- At stage (2) of fact-finding, groups of the students were creative in collecting the data obtained from field surveys, over $80 \%$ did not experience problems in finding the field data.

- At stage (3) of problem-finding, the students were less creative in finding problems. At this stage, about 50\% of students were difficult in modeling from real problems into the minimum cost flow model, the maximum flow model, matching model and VRP variants, so they needed a guidance,

- At stage (4) of idea finding, the students were creative in finding the ideas for choosing the algorithms used. Over $85 \%$ of students did not experience obstacles because they had understood during off-line learning.

- At stage (5) of idea evaluation and (6) idea implementation, the students were creative in implementing the program which was the product of the research grant [12], and analyzing and interpreting the program,. More than $80 \%$ of student groups did not face problems.

Fig. 2 shows some screenshots of a web-based application to solve VRP problems.



Fig. 2. Markers in map to determine depot and customer location 


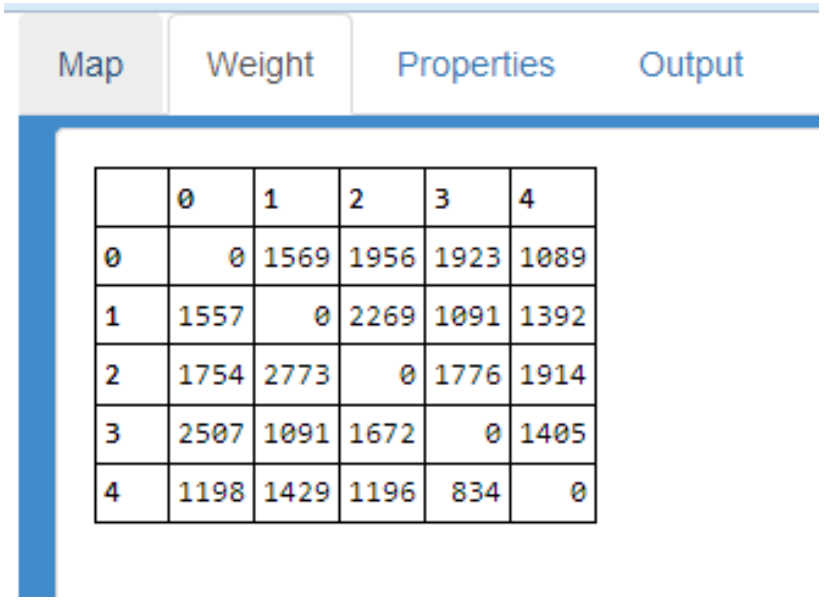

Fig. 3. Distance table from Distance Matrix Service

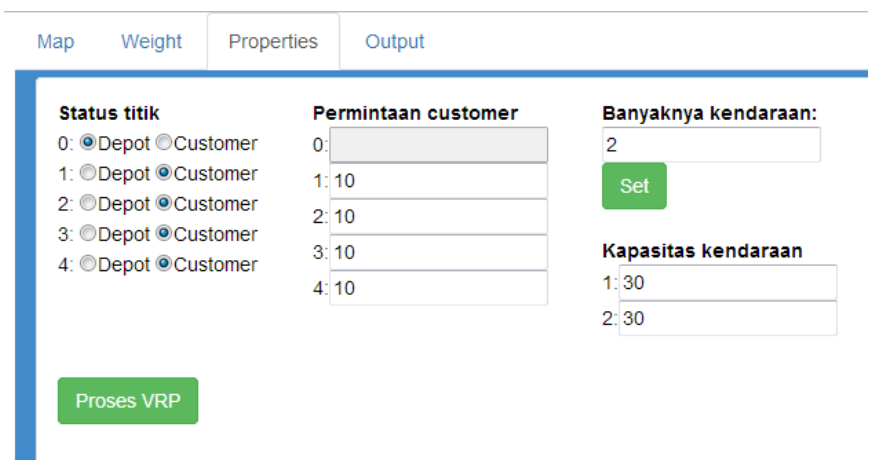

Fig. 4. Determining customer's demand

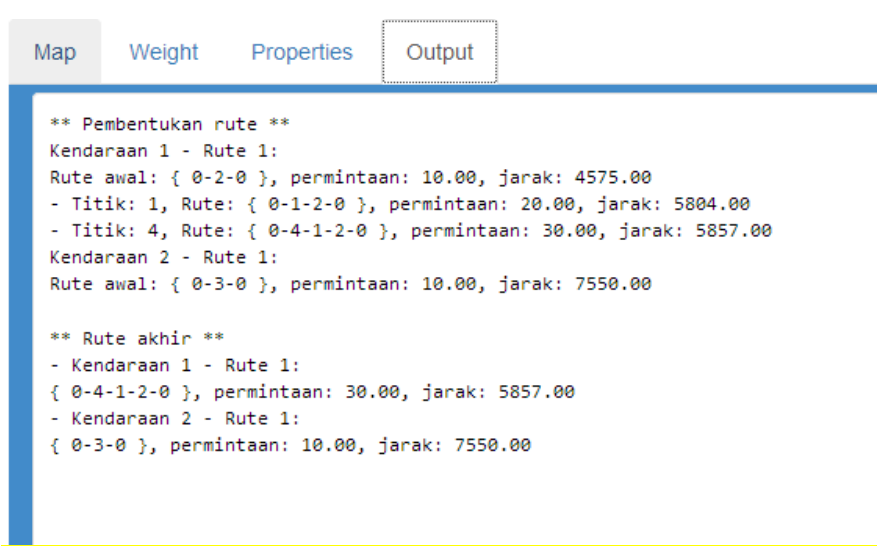

Fig. 5. Route as solution in textual form

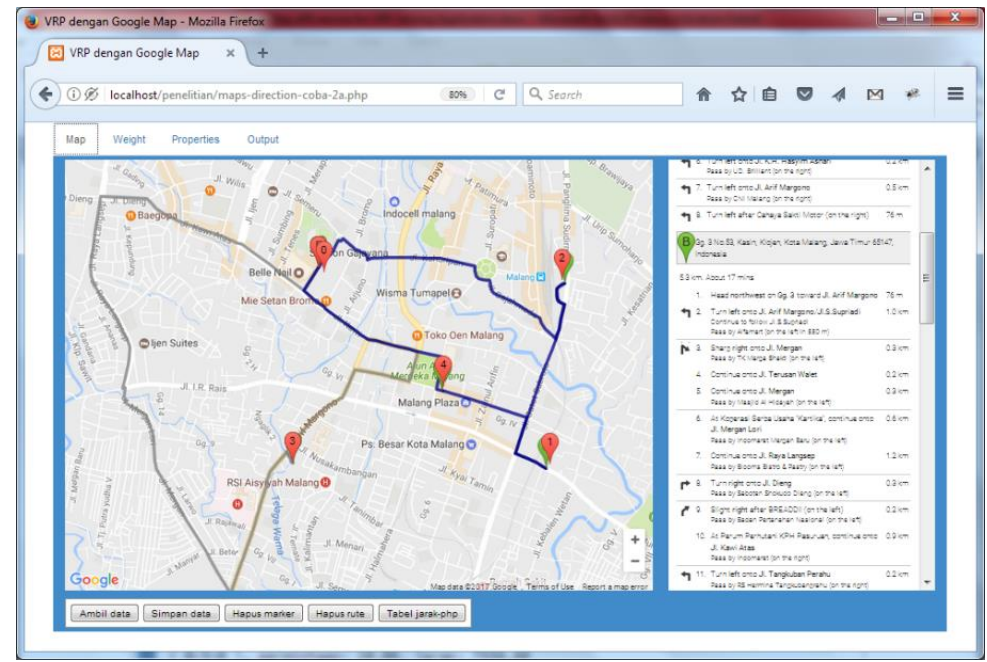

Fig. 6. Route as solution in graphical form in the map

Here some titles of survey results for the real-case problemsolving.

- Optimization of Shoe Distribution by Multiple Traveling Salesman Problem (MTSP) at PT Karya Mitra Budi Sentosa

- Optimizing Route of Letter and Package Distribution Using Algorithms on Traveling Salesman Problem with Time Windows at PT Pos Indonesia (Persero) Malang

- Optimization of Vehicles for Cigarette Distribution at PT Wheat Using Algorithms on Maximum Flow

- Implementation of Algorithm on Maximum Flow to Optimize Product Distribution in CV Permata Agro Mandiri

- Usage of Minimum Cost Flow on Goods Distribution in UD. Sehati Kedungwaru Tulungagung

- Optimizing the distribution of $3 \mathrm{~kg}$ LPG Using Minimum Cost Flow Application at PT. Dwi Tunggal Jaya Malang

- Optimization of Ruko Development Scheduling in Sukun Malang Using Network Planning with Win QSB Tools.

- Application of VRP variant algorithms in CV. Gem Agro Mandiri Banaran Bumiaji Batu

- Optimizing Package Distribution Route Using Algorithms on VRPTW at PT Pos Indonesia (Persero) Malang

- Optimizing Tentor Assignments on Peter's Tutoring using Algorithms on Matching 


\section{CONCLUSION}

The implementation of blended learning innovation in the Graph Theory Application course, by combining learning in the form of face-to-face, offline, online and direct experience in the field, could improve student creativity. This result was in line with the demands of education in the $21^{\text {st }}$-century, the rapid development of science and technology and the development of information, which demand highly skilled resources that involve systematic critical thinking, logical, creative and effective cooperative skills. Problem-solving ability is one indicator of creative thinking ability which can be used for CPS model.

In further research, problem-solving abilities can be studied in terms of student creative products that include dimensions of creativity, fluency, flexibility, and novelty.

\section{ACKNOWLEDGEMENTS}

This article is a part of Applied Product Research year 2017 conducted by Darmawan Satyananda and Sapti Wahyuningsih (first year of 2-year research plan), titled "Utilization of Google Map Service for VRP Problem-Solving Application". This research was funded by Directorate of Research and Community Service, Kemenristekdikti.

\section{REFERENCES}

[1] Badan Nasional Standart Pendidikan (BNSP), "Paradigma Pendidikan Nasional abad XXI," 2010.

[2] C. R. Graham and R. Robison, "Realizing the transformational potential of blended learning: comparing cases of transforming blends and enhancing blends in higher education," in Blended Learning Research Perspectives, A. G. Picciano and C. D. Dziuban, Eds. Sloan-C ${ }^{\mathrm{TM}}, 2007$.

[3] D. R. Garrison and H. Kanuka, "Blended learning: Uncovering its transformative potential in higher education," Internet High. Educ., vol. 7, no. 2, pp. 95-105, 2004.

[4] D. R. Garrison and N. . Vaughan, Blended learning in higher education: Framework, principles and guidelines. San Francisco: Jossey-Bass. San Francisco: Jossey-Bass, 2008.

[5] J. S. Mtebe and C. Raphael, "Students' experiences and challenges of blended learning at the University of Dar es Salaam, Tanzania," Int. J. Educ. Dev. Using Inf. Commun. Technol., vol. 9, no. 3, pp. 124-136, 2013.

[6] G. Lefoe, "Creating constructivist learning environments on the web: The challenge in higher education," in ASCILITE '98, 1998, pp. 453464.

[7] S. Wahyuningsih, D. Satyananda, and D. Hasanah, "Kajian Karakteristik Solusi Varian Traveling Salesman Problem (TSP) dan Aplikasinya," in Prosiding Seminar Nasional Matematika dan Pendidikan Matematika, 2015, pp. 490-498.

[8] S. Wahyuningsih and D. Satyananda, "Characteristic Studies of Solution the Multiple Trip Vehicle Routing Problem (MTVRP) and its Application in Optimization of Distribution Problem," in Proceeding of International Seminar on Mathematics Education and Graph Theory, 2014, pp. 569-578.

[9] S. Wahyuningsih and D. Satyananda, "Pengembangan Modul Penerapan Teori Graph berbasis ICT sebagai Pedoman Praktek Kerja Lapangan (PKL) Mahasiswa Jurusan Matematika di Industri,” in Prosiding Konferensi Nasional Matematika ke 17, 2014, pp. 575-590.
[10] S. Wahyuningsih and D. Satyananda, "The Characteristics Study of Solving Variants of Vehicle Routing Problem and Its Application on Distribution Problem. Proceeding of International Conference on Research, Implementation and Education of Mathematics and Science, pp. 101-108. Yogyakarta: Uni," in Proceeding of International Conference On Research, Implementation And Education Of Mathematics And Sciences, 2015, pp. 101-108.

[11] S. Wahyuningsih, "Analisa local search untuk perbaikan solusi varian Vehicle Routing Problem pada permasalahan optimasi," in Prosiding Seminar Nasional Integrasi Matematika dan Nilai Islam (SiManis), 2017, pp. 342-348.

[12] S. Wahyuningsih and D. Satyananda, "Implementations of TSP-VRP Variants for Distribution Problem," Glob. J. Pure Appl. Math., vol. 12, no. 1, pp. 723-732, 2016.

[13] D. Satyananda, "Google Map API service for VRP Solving Application," in Prosiding SI MaNIs (Seminar Nasional Integrasi Matematika dan Nilai-Nilai Islami), 2017, pp. 240-246.

[14] G. Torrisi-Steele, "This thing called blended learning - a definition and planning approach," Res. Dev. High. Educ. Reshaping High. Educ., vol. 34, pp. 360-371, 2011.

[15] E. A. Silver and J. Cai, "An analysis of arithmetic problem posing by middle school students," J. Res. Math. Educ., vol. 27, no. 5, pp. 521539, 1996.

[16] G. A. Davis, Creativity is forever. Kendall Hunt Publishing Company, 2004.

[17] S. Krulik and J. A. Rudnick, The New Sourcebook for Teaching Reasoning and Problem Solving in Elementary School. Needham Heights, Massachusetts: Allyn \& Bacon, 1995.

[18] R. Subanji and A. M. Supratman, "The Pseudo-Covariational Reasoning Trought Processes in Constructing Graph Function of Reversible Event Dynamics Based on Assimilation and Accomodation Frameworks," Res. Math. Educ. J. Korean Soc. Mathe. Educ/Series D, vol. 19, no. 1, pp. 61-79, 2015.

[19] S. Subanji and T. Nusantara, "Thinking Process of Pseudo Construction in Mathematics Concepts," Int. Educ. Stud., vol. 9, no. 2, p. 17, 2016.

[20] S. Mustafa, T. Nusantara, S. Subanji, and S. Irawati, "Mathematical Thinking Process of Autistic Students in Terms of Representational Gesture," Int. Educ. Stud., vol. 9, no. 6, p. 93, 2016.

[21] I. D. Hastuti, T. Nusantara, and H. Susanto, "Constructive metacognitive activity shift in mathematical problem solving," Educ. Res. Rev., vol. 11, no. 8, p. 656, 2016.

[22] T. N. Sutarto and S. Subanji, "Local conjecturing process in the solving of pattern generalization problem," Educ. Res. Rev., vol. 11, no. 8, pp. 732-742, 2016.

[23] A. Prayitno, S. Subanji, and M. Muksar, "Refractive Thinking with Dual Strategy in Solving Mathematics Problem," IOSR J. Res. Method Educ., vol. 6, no. 3, pp. 49-56, 2016.

[24] E. A. Silver, "Fostering creativity through instruction rich in mathematical problem solving and problem posing," $Z D M$, vol. 29 , no. 3, pp. 75-80, 1997.

[25] S. S. Leung, "On the role of creative thinking in problem posing," ZDM, vol. 29, no. 3, pp. 81-85, Jun. 1997.

[26] N. Urquhart, C. Scott, and E. Hart, "Using graphical information systems to improve vehicle routing problem instances," in Proceedings of the 15th annual conference companion on Genetic and evolutionary computation, 2013, pp. 1097-1102.

[27] G. Svennerberg, Beginning Google Maps API 3. Apress, 2010.

[28] D. Pérez-Marín, L. Santacruz, and M. Gómez, "A proposal for a blended learning methodology and how to apply it with university students," Procedia-social Behav. Sci., vol. 46, pp. 5458-5462, 2012. 